\title{
Application of Methods Combined Treatment for Obtaining Welding Wire from Silumins
}

\author{
Ruslan E. Sokolov* and Sergey B. Sidelnikov \\ Siberian Federal University \\ 79 Svobodny, Krasnoyarsk, 660041, Russia
}

Received 18.12.2014, received in revised form 09.02.2015, accepted 28.02.2015

Developed technology of obtaining rods and wires from silumins using casting in electromagnetic crystallizer and follow combined rolling-extruding and drawing. Were carried studies of properties of deformed semi-finished products and obtained experimental batches of welding wire from alloys AlSi5 and AlSil2.

Keywords: combined treatment, rolling, extruding, welding wire, silumin.

\section{Применение методов совмещенной обработки}

\section{для получения сварочной проволоки из силуминов}

\author{
Р.Е. Соколов, С.Б. Сидельников \\ Сибирский федеральный университет \\ Россия, 660049, Красноярск, пр. Свободный, 79
}

Разработана технология получения прутков и проволоки из силуминов с использованием литья в электромагнитный кристаллизатор с последующей совмещенной прокаткойпрессованием и волочением. Проведены исследования свойств деформированных полуфабрикатов и получены опытные партии сварочной проволоки из сплавов АК5 и АК12.

Ключевые слова: совмещенная обработка, прокатка, прессование, сварочная проволока.

Aluminum and aluminum alloys due to their unique technical and operational characteristics occupy an important place in modern industry. The presence of such properties as high electrical conductivity and corrosion resistance combined with low weight led to the fact that aluminum and its alloys are widely used in engineering, electric power industry, transportation, aviation, and other branches of industry. A special place in the structure of production of semi-finished products from aluminum and its alloys occupies wire, which is used to make electricity transmission lines, electric transport ropes, cables, electrodes, welding rod, welding wire, etc. Recently, there was a great need

(c) Siberian Federal University. All rights reserved

* Corresponding author E-mail address: sokolov.sfu@gmail.com 
for the welding wire from silumins due to the high mechanical and corrosion properties of these alloys. These products are widely used in military, space and aviation industry for welding aircraft constructions and are widely used in welding defects in the foundry industry. The high cost semifinished products from silumins due to large labor-intensive production limits their widespread use in other industries and makes the problem of the development of new technologies to produce deformed products from them actual.

Analysis of published data on the trends of industrial development of pressed production of small cross-sectional and wire from aluminum alloys showed that one of them is the use of the combined processes of metal allow obtaining technical and economic advantages by reducing the number of cycles of manufacturing technology of these products.

Existing production technologies of small cross-sectional press-articles on horizontal hydraulic presses have several disadvantages, most important of which are associated with a discrete and high energy intensity of the process. On the other hand, there are a number of ways of continuous pressing, such as Conform, Linex and Extrolling which have a high yield, low energy consumption compared with traditional methods of pressing, and the possibility of deformation continuous cast billets in one cycle.

In the works of Russian and foreign scientists, B. Avitsur, R. Grjiba, V.L. Berejnoy, M.S. Gildengorn, F.S. Gilevich, N.N. Dovzhenko, V.N. Kornilov, V.N. Peretyatko, S.B. Sidelnikov and others, proposed technical solutions to implement various options of process combined rollingextruding (CRE) [1, 2] and expand the technological capabilities of the process when receiving long products from different metals and alloys. However, the use of the CRE for obtaining extruded semi-finished products of small cross-section from hardly deformable aluminum-silicon alloys such as AlSi5 and AlSi12 studied little and requires further theoretical and experimental research. Several papers (D.Y. Gorbunov and others) for these products proposed to use technology including at the first stage improving the plastic properties of cast billets through the use of complex alloying of aluminum-silicon alloys in combination with high cooling rates during casting and extruding on hydraulic presses of cast billets in the second stage. However, this method is technologically advantageous for large volumes of production and quite laborious as it involves a large number metallurgical conversions using multiple deformation and heat treatment operations. At the same time, the modern level of development technology using electromagnetic crystallizer (EMC) allows to obtain billets of small size with high plastic properties ideal for the combined treatment process of hardly deformable alloys.

The analysis of metal forming and temperature conditions of the process by computer simulation using the software package DEFORM 3D (Fig.1) showed, that in the area of rolling coordinate grid units which are located at the contact surface with rolls ahead the central metal layers. After the vertical axis passing through the center of the rolls speed grid points in the periphery and in the center of billet gradually aligned and become equal.

Experimental studies were performed on cast billets obtained in electromagnetic crystallizer from alloys mark AlSi5 and AlSi12. During the research varied factors were: temperature (T), strain rate $(\xi)$ and draw ratio $(\mu)$, calculated as $\mu=F_{\text {bil }} / F_{\text {prod }}$, where $F_{b i l}$ and $F_{\text {prod }}$ - accordingly cross sectional area of billet and extruded semi-finished product. In order to obtain a set of pilot data for regression analysis of the results of theoretical investigations and modeling process CRE each of these factors varied in 


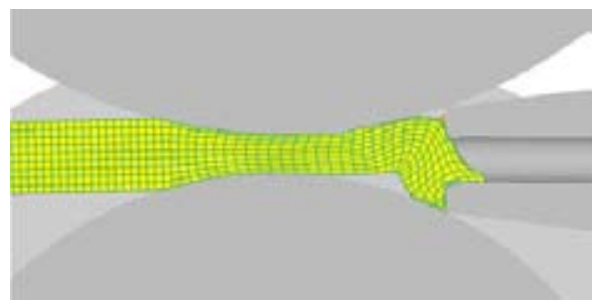

a

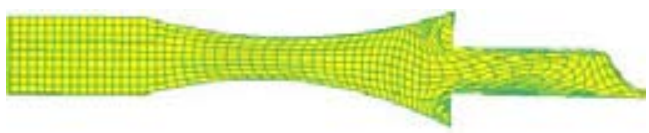

c

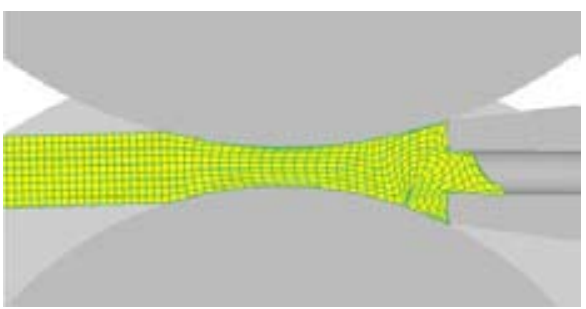

b

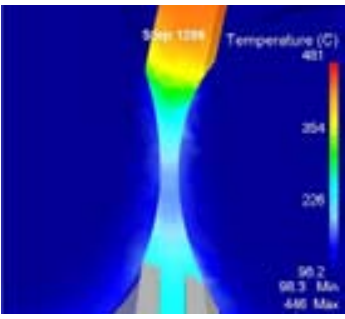

d

Fig. 1. Forming changing of metal in various stages of the process CRE: $a$ - early stage of decompression; $b-$ stage of decompression and starting extruding of press-article; $\mathrm{c}$ - grid in the steady process; $\mathrm{d}$ - temperature changes along the length of semi-finished product

a range of values. Temperature was varied from 480 to $550{ }^{\circ} \mathrm{C}$, strain rate from 0,74 to $1,49 \mathrm{~s}^{-1}$, draw ratio from 4,4 to 14,3 . The measurements were the force acting on the matrix and on the rolls during the deformation of the metal.

In the first phase of research with using EMC obtained cast billets from alloys AlSi5 and AlSi12 diameter $15 \mathrm{~mm}$. Analysis of the microstructure at different magnifications showed that the eutectic composition is subtly differentiated, and silicon particles in it so dispersed that it is not visible even at 1500 -fold increase. Thus, the ingots produced using the EMC have higher plastic properties and can be treated to metal forming at sufficiently high degrees of deformation. In the second stage for experimental studies and modeling of the combined processing used an installation CRE-200 which was equipped with strain-gauge equipment and provide a number of experiments on the effect of varying parameters on power conditions of the process. The results of experimental studies on the power parameters of the process CRE are given in Fig. 2 and 3.

Based on research and new technological solutions developed technology for producing welding wire Sv.AlSi12 which consisted of the following technological conversions. In the first stage with EMC obtained cast billet with a diameter of $15 \mathrm{~mm}$ with increased plastic properties. Further obtained billet heated to a temperature $550^{\circ} \mathrm{C}$ and subjected combined rolling-extruding with strain rate $\xi=0,74 \mathrm{~s}^{-1}$ and draw ratio $\mu=7,3$. In the last phase obtained rod diameter $7 \mathrm{~mm}$ subjected cold drawing for obtaining wire diameter $2 \mathrm{~mm}$. Mechanical test results at each stage of the technological processing are presented in Table 1. It should be noted that the plastic and strength properties of the obtained cast billets significantly exceed the requirements of State Standard R 50511-93, which allows receiving deformed semi-finished products of set sizes. 


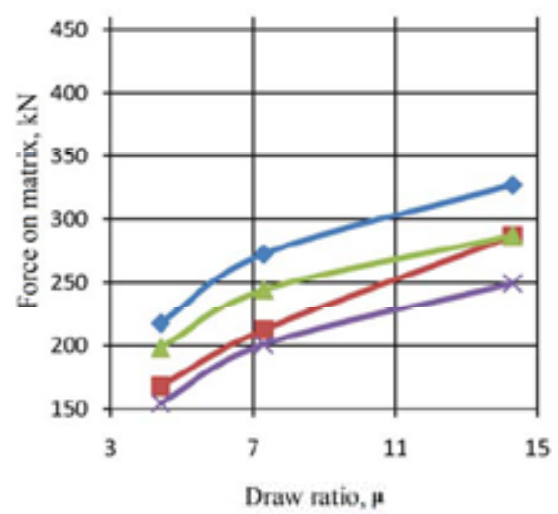

$\leadsto \mathrm{T}-480^{\circ} \mathrm{C}, \xi=0,74 \mathrm{~s}$

$\rightarrow-\mathrm{T}_{\mathrm{s}}-480^{\circ} \mathrm{C}, \xi-1.49 \mathrm{~s}^{*}$

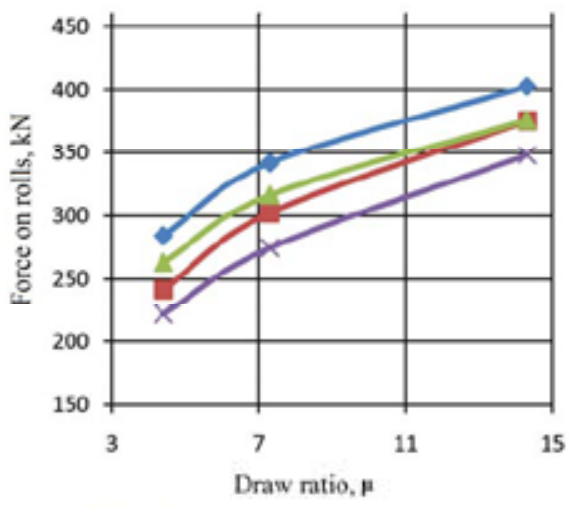

$-\mathrm{T}_{\mathrm{s}}=550^{\circ} \mathrm{C}, \xi=0,74 \mathrm{~s}^{-1}$

$\rightarrow-T_{i}-550^{\circ} \mathrm{C}, \xi-1,49 \mathrm{~s}^{-1}$

Fig. 2. The dependence of the power parameters process CRE from draw ratio $(\mu)$, billet heating temperature $\left(T_{b i l}\right)$ and strain rate $(\xi)$ for alloy AlSi5
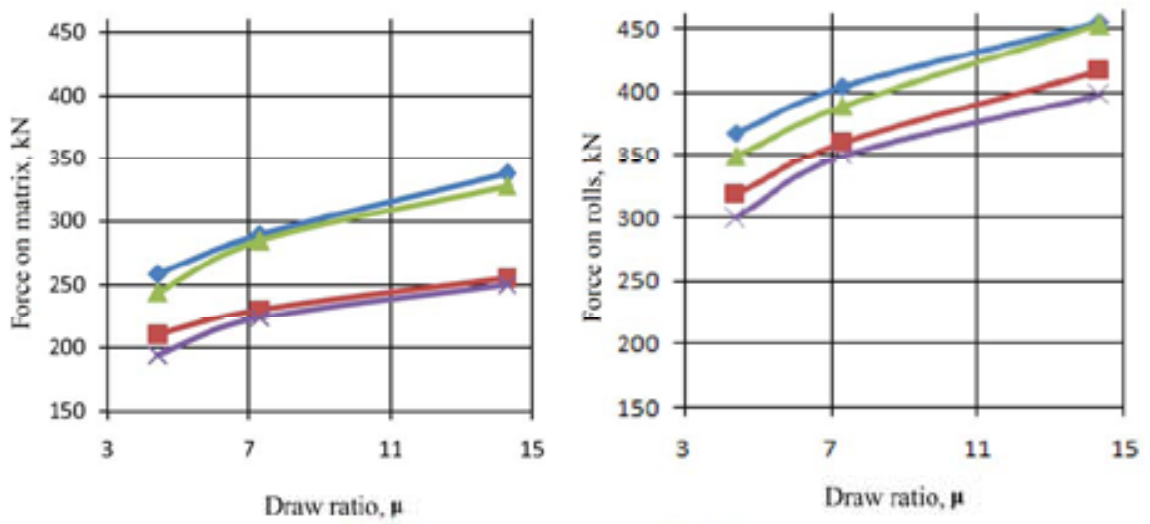

$0 \mathrm{~T}-480 \circ \mathrm{C}, \xi=0,74 \mathrm{~s}^{4}$
$-\mathrm{T}-\mathrm{T}-4800^{\circ} \mathrm{C}, \xi-1,49 \mathrm{~s}^{-1}$

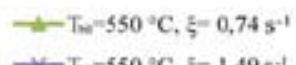

Fig. 3. The dependence of the power parameters process CRE from draw ratio $(\mu)$, billet heating temperature $\left(T_{b i l}\right)$ and strain rate ( $\xi)$ for alloy AlSi12

Experimental batches of wire obtained by the developed technologies have been transferred to FSUE «SPA «Applied mechanics» (Zheleznogorsk) and in tests it was found that this wire of mark Sv.AlSi12 meets the requirements of TC 1-808-274-2003 and can be used in the production of solder waveguides used in aerospace and aeronautical engineering that confirmed by the act of pilot testing and the act of implementation.

Thus, the results of studies using the combined methods of treatment was developed and implemented new production technology of welding wire from silumins. Use of this technology could substantially reduce the cost of production by minimizing the number of operations and get quality deformed products of small cross-section. 
Table 1. Mechanical properties of semi-finished products from silumins

\begin{tabular}{|l|l|c|c|}
\hline \multirow{4}{*}{ Mark of alloy } & \multicolumn{1}{|c|}{ Type of product } & \multicolumn{2}{c|}{ Mechanical properties } \\
\cline { 2 - 4 } & & $\sigma_{\mathrm{B}}, \mathrm{MPa}$ & $\delta, \%$ \\
\hline \multirow{5}{*}{ AlSi5 } & cast billet diameter $15,0 \mathrm{~mm} ;$ & 270,0 & 15,0 \\
\cline { 2 - 4 } & rod diameter 7,0 mm; & 280,3 & 9,0 \\
\cline { 2 - 4 } & wire diameter 3,0 mm; & 382,0 & 4,8 \\
\cline { 2 - 4 } & wire diameter 2,6 mm; & 376,7 & 4,0 \\
\cline { 2 - 4 } & wire diameter 2,0 mm; & 413,8 & 2,8 \\
\hline \multirow{5}{*}{ A1Si12 } & cast billet diameter 15 mm; & 290,8 & 14,8 \\
\cline { 2 - 4 } & rod diameter 7,0 mm; & 402,2 & 20,2 \\
\cline { 2 - 4 } & wire diameter 3,0 mm; & 425,1 & 4,0 \\
\cline { 2 - 4 } & wire diameter 2,5 mm; & 445,7 & 3,0 \\
\cline { 2 - 4 } & wire diameter 2,0 mm; & 1,5 \\
\hline
\end{tabular}

\section{References}

[1] Sidelnikov S.B., Dovzhenko N.N., Zagirov N.N. Combined methods of treatments of nonferrous metals and alloys: a monograph. M.: MAKS Press, 2005. P. 344.

[2] Dovzhenko N.N., Belyaev S.V., Sidelnikov S.B. and others. Extruding of aluminum alloys: modeling and control of thermal conditions: monograph. Krasnoyarsk: Siberian Federal University, 2009. 256 p. 